REVIEW

\title{
Variation in thyroid function in subclinical hypothyroidism: importance of clinical follow-up and therapy
}

\author{
Jesper Karmisholt, Stig Andersen and Peter Laurberg \\ Department of Endocrinology and Medicine, Aalborg Hospital, Aarhus University Hospital, 9000 Aalborg, Denmark \\ (Correspondence should be addressed to J Karmisholt; Email: jsk@rn.dk)
}

\begin{abstract}
Subclinical hypothyroidism ( $\mathrm{SCH}$ ) is a common condition that is often observed without therapy. However, no evidence-based recommendation exists with regards to how patients with untreated SCH should be monitored.

Monitoring involves regular assessment of symptoms and signs of hypothyroidism (HYPO) and biochemical tests of thyroid function. An important question when repeated tests of thyroid function are performed is how large a difference in test results is needed to be confident that the change is real and not just due to chance variation.

Recent data show that the least significant difference between two tests in SCH is $40 \%$ for TSH and 15\% for free thyroxine and free triiodothyronine, with $90 \%$ confidence. Furthermore, monitoring has to be based on biochemical function testing because serial evaluation of symptoms and signs related to HYPO is rather insensitive in detecting worsening of thyroid insufficiency.

When the presence of thyroid peroxidase auto-antibodies (TPO-Ab) in serum has been demonstrated, repeated measurements do not add much useful information in the monitoring of individual subclinical hypothyroid patients, as levels of TPO-Ab vary in parallel with TSH in these patients. Lastly, we discuss how differences in the monitoring procedure influence the diagnostic outcome, and we suggest a follow-up approach for untreated subclinical hypothyroid patients.
\end{abstract}

European Journal of Endocrinology 164 317-323

\section{Introduction}

Subclinical hypothyroidism $(\mathrm{SCH})$ is a state where serum TSH is above the upper reference limit for the assay while an estimate of free thyroxine $\left(\mathrm{fT}_{4}\right)$ is within the reference interval of the assay. SCH is a frequently observed biochemical abnormality (1-3), and the prevalence is especially high in populations with high iodine intake $(2,4,5)$, in older age groups and women $(6,7)$ and in Caucasians (8). Currently, the most widely accepted interpretation of the biochemical findings in $\mathrm{SCH}$ is that the increased TSH is an indication of mild hypothyroidism (HYPO) with a slightly reduced peripheral thyroid hormone effect. The causes of SCH resemble the causes of HYPO, where autoimmune thyroiditis is the most frequent cause (9). Table 1 lists studies of the natural history of SCH (10-18). Progression of SCH to HYPO is in the order of $5-8 \%$ /year. Normalisation of thyroid function is another possible outcome, and many patients have stable $\mathrm{SCH}$ and do not experience systematic deterioration in thyroid function for years (10-18).

It has been, and still is, much debated whether the abnormality should be treated with levothyroxine $\left(\mathrm{L}-\mathrm{T}_{4}\right)$ or not (19-24). Biondi \& Cooper (25) have authored an exhaustive review on the aetiology, epidemiology and consequences of SCH and on treatment effects on SCH. A recently published large meta-analysis of 11 prospective cohort studies showed increased risk of cardiovascular morbidity and mortality in patients with TSH above, but not below, $10 \mathrm{mU} / \mathrm{l}$ and no increase in total mortality (26). A Cochrane review regarding the effect of $\mathrm{L}_{-} \mathrm{T}_{4}$ replacement therapy in $\mathrm{SCH}$ based on randomised clinical studies could not demonstrate consistent evidence of reduced cardiovascular morbidity, improved quality of life or amelioration of symptoms in the treated groups (27), and mortality has not been studied in randomised controlled trials. Overall, data from state-of-the-art randomised clinical trials with recording of adverse events and with sufficient power to be conclusive with regard to beneficial effect of $\mathrm{L}_{-} \mathrm{T}_{4}$ treatment in $\mathrm{SCH}$ are lacking. However, consensus has emerged to recommend treatment in women who are pregnant or who plan pregnancy and in patients with serum TSH persistently above $10 \mathrm{mU} / \mathrm{l}$. In addition, many will recommend treatment in patients with goitre or in patients with symptoms and signs suggesting $\operatorname{HYPO}(23,24)$.

A large proportion of patients with SCH do not conform to the categories where therapy is recommended. 
Table 1 Follow-up studies with more than two serum samples from each patient with SCH. In the studies, SCH was typically defined as serum TSH above upper reference limit and with a normal serum level of an estimate of thyroxine.

\begin{tabular}{|c|c|c|c|c|c|c|}
\hline Authors (references) & $\begin{array}{c}\text { Publication } \\
\text { year }\end{array}$ & Patient types & $\begin{array}{c}\text { Number } \\
\text { of patients }\end{array}$ & $\begin{array}{c}\text { Follow-up } \\
\text { time (years) }\end{array}$ & $\begin{array}{c}\text { Follow-up } \\
\text { intervals } \\
\text { (months) }\end{array}$ & $\begin{array}{c}\text { Risk of } \\
\text { developing } \\
\text { HYPO } \% \text { year } \\
(\%)\end{array}$ \\
\hline Nystrom et al. (10) & 1981 & $\mathrm{TSH}<14 \mathrm{mU} / \mathrm{l}$ & 16 & 4 & 12 & 18 \\
\hline Tunbridge et al. (11) & 1981 & $\mathrm{TSH}>6.0 \mathrm{mU} / \mathrm{l}$ or $+\mathrm{TPO}-\mathrm{Ab}$ & 163 & 4 & 24 & 1.2 \\
\hline Gray et al. (12) & 1983 & TSH 5.6-46.3 mU/l, diabetes pt. & 59 & 4.2 & $12-36$ & 3.6 \\
\hline Rosenthal et al. (13) & 1987 & $\mathrm{TSH}>4 \mathrm{mU} / \mathrm{l}$, elderly pt. & 23 & 4 & 12 & 7.5 \\
\hline Parlè et al. (14) & 1991 & $\mathrm{TSH}>5 \mathrm{mU} / \mathrm{l}$, age $>60$ years & 73 & 1 & 3 & 18 \\
\hline Kabadi (15) & 1993 & $\mathrm{TSH}>5.0 \mathrm{mU} / \mathrm{l}$ & 30 & 8.2 & $3-6$ & 6.5 \\
\hline Huber et al. (16) & 2002 & $\mathrm{TSH}>4 \mathrm{mU} / \mathrm{l}$ & 82 & $0.5-26.3$ & 12 & 3.0 \\
\hline Diez et al. (17) & 2004 & $\mathrm{TSH}>5.0 \mathrm{mU} / \mathrm{l}$, age $>55$ years & 107 & $0.5-6$ & 6 & 9.8 \\
\hline Rosario et al. (18) & 2009 & $\mathrm{TSH}<10 \mathrm{mU} / \mathrm{l}$, women & 117 & 3 & 6 & 9.1 \\
\hline
\end{tabular}

aHYPO - hypothyroidism, typically defined as serum TSH above upper reference limit and with a low serum level of an estimate of thyroxine. The calculated risk of developing HYPO per year was calculated as the total number of participants who developed HYPO divided by the follow-up time. In a few studies, the participants had different follow-up times, and calculation on raw data may give a slightly different estimate.

After an initial diagnostic work-up, regular biochemical control of thyroid function without therapy is recommended in these SCH patients (23). The diagnostic work-up includes a history, physical examination, biochemical measurements of TSH, an estimate of $\mathrm{fT}_{4}$ and thyroid peroxidase auto-antibodies (TPO-Ab) in serum and possibly an ultrasound examination of the thyroid gland. Serum TSH above the upper reference limit may be a transient finding, and confirmatory tests of TSH and $\mathrm{T}_{4}$ obtained 2 weeks to 3 months after measuring a single increased TSH are recommended (23). Once the diagnosis of SCH has been confirmed, a programme of regular monitoring has to be established.

The rationale for regular monitoring of patients with $\mathrm{SCH}$ is the possibility of early detection of development of $\mathrm{HYPO}$ as $\mathrm{SCH}$ patients have increased risk of developing HYPO. Another argument for regular monitoring is to recognise symptoms and signs that may be attributable to HYPO and thus potentially may be ameliorated with $\mathrm{L}-\mathrm{T}_{4}$ replacement therapy.

We discuss the data available to clinicians to judge if a certain change in symptoms and signs or change in results of thyroid functions tests indicates progression in the thyroid failure or if the results are part of random variation.

\section{Intra-individual variation in thyroid function tests}

The intra-individual variation of thyroid function tests has been studied in individuals with normal thyroid function (28-37). This has revealed both a considerable circadian rhythm and a small seasonal variation in TSH secretion, but over time TSH in an individual varies within a range of only half of a population-based reference range. The narrow intra-individual variation compared with the inter-individual variation makes population-based reference intervals less suitable for use in serial measurements (38), because a TSH change that is significant for the individual may still occur within the TSH reference interval. In patients with stable $\mathrm{SCH}$, i.e. no systematic deterioration or improvement of thyroid function over 1 year, the intraindividual variation in serum TSH of $16 \%$ resembles that of euthyroid individuals. On the other hand, the variation in $\mathrm{fT}_{4}$ is $4.1 \%$ and $4.0 \%$ for free triiodothyronine $\left(\mathrm{fT}_{3}\right)$ in SCH patients compared with $9.5 \%$ for $\mathrm{fT}_{4}$ and $7.9 \%$ for $\mathrm{fT}_{3}$ in euthyroid individuals $(35,39)$.

The interpretation of the test results of repeated measurements of a variable that may already be outside the reference range is different compared to a case finding or a diagnostic situation. In the serial measurement situation, knowledge of the intra-individual variation is important for correct interpretation of improvement or worsening of disease $(40,41)$. Is the difference between the previous and the current test result caused by random variation or is it a sign of change in disease activity? Figure 1 illustrates the principle in the calculation of a repeated test result based on the knowledge of the intra-individual variation. It is a plot of the probability of a true change versus the relative difference between two tests. A significance level of $90 \%$ is often considered clinically relevant. From this, the least significant difference between two tests, called the reference change value, for TSH and $\mathrm{fT}_{4}$ or $\mathrm{fT}_{3}$ has been estimated to be 40 and $15 \%$ respectively (42). In other words, if the result of a repeated TSH test is within the $\pm 40 \%$ range of the previous TSH test, then the result may well be due to random variation, whereas if the result is outside the $\pm 40 \%$ range, the difference represents a true change in thyroid function with $90 \%$ confidence.

\section{Correlations of serum TSH to other biochemical parameters}

In individual patients with $\mathrm{SCH}$, variations in serum TSH correlate significantly with variations in $\mathrm{fT}_{4}$, 


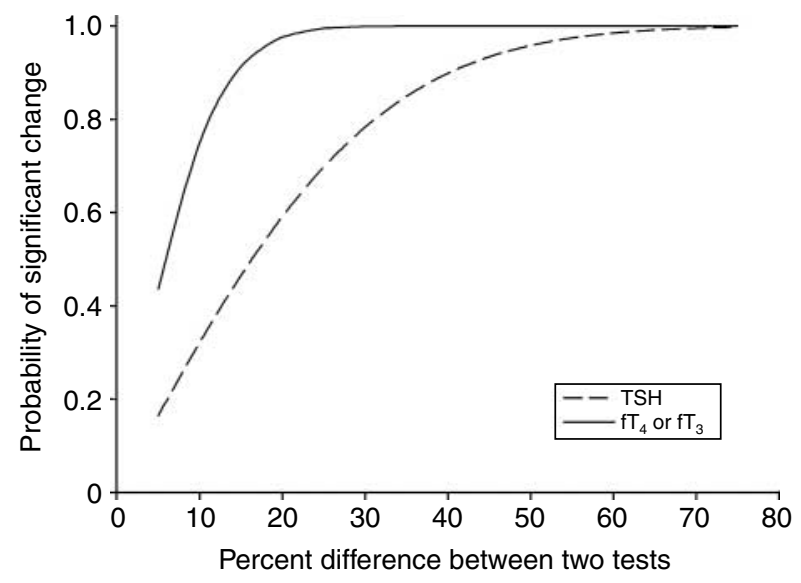

Figure 1 Relative differences between two serum TSH measurements (dashed line) and of $\mathrm{fT}_{4}$ or $\mathrm{fT}_{3}$ (solid line) and the corresponding probability this represents of significant change shown on the $y$-axis. The variations of $\mathrm{fT}_{4}$ and $\mathrm{fT}_{3}$ are almost identical, and a single line represents both parameters. The probability of a significant change between two test results was calculated from: relative difference between two tests $=Z \times C V_{\text {total }}$ $\times 2^{1 / 2}$, where $Z$ denotes the confidence interval, i.e. $Z=1.65$ for $90 \%$ Cl (40). See Ref. (42) for details.

TPO-Ab in serum and with urinary iodine excretion as evaluated from within-person correlations (43).

We studied whether the fluctuations in TSH and TPO-Ab in serum and urinary iodine excretion were in phase or not by calculating Pearson coefficients of correlations for the individual patients with time shifts between the variables. There was a positive correlation between TPO-Ab and TSH over a broad time interval from TPO-Ab measured 2 months before, to 1 month after TSH. The only substantial correlation between urinary iodine excretion and TSH was obtained using the urinary iodine excretion value taken 1 month before the TSH value. It was also evident that the urinary iodine excretion obtained 1 month before the TPO-Ab value gave the highest and positive mean correlation value. This may indicate an additive effect of an increase in iodine intake and a surge in thyroid autoimmunity on thyroid failure in patients with $\mathrm{SCH}$. Supplementary iodine given to individuals with euthyroid Hashimoto's thyroiditis has previously been associated with increased risk of a decline in thyroid function without change in thyroid autoimmunity (44), whereas serum TSH and $\mathrm{TPO}-\mathrm{Ab}$ increased in some patients with euthyroid endemic goitre treated with potassium iodide (45).

\section{Should other parameters than serum TSH and serum $T_{4}$ be measured?}

Both TSH and $\mathrm{T}_{4}$ are used for the definition of SCH, and measurement of both hormones is paramount. The presence of TPO-Ab in serum is an independent risk factor for the development of HYPO in patients with
SCH $(16,17,46)$. Serum values of TPO-Ab and TSH have a parallel course in patients with SCH (43). In other words, regular measurement of TPO-Ab in addition to TSH confirms the significance of a change in TSH. It plays no particular role as an independent indicator of disease activity or severity.

In clinical practice, HYPO-related symptoms and signs are often the argument for institution of $\mathrm{L}_{-} \mathrm{T}_{4}$ treatment. Randomised clinical trials on HYPO-related symptoms and signs in patients with SCH have shown contradictory effects of $\mathrm{L}_{-} \mathrm{T}_{4}$ replacement therapy (27, 47-53). As a consequence of the variation in results of thyroid function test in patients with $\mathrm{SCH}$, diagnoses may shift between euthyroidism, $\mathrm{SCH}$ and HYPO. In a 1-year study of patients with $\mathrm{SCH}$, symptoms and signs related to HYPO varied considerably between patients. However, there was no correlation between symptoms and signs on the one hand and TSH abnormality on the other hand when different patients were compared. Moreover, in the individual patient, there was no correlation between the diagnosis based on a given test result and the symptoms of HYPO at the same point in time (42).

Diez et al. (17) found that patients who developed HYPO had higher probability of experiencing symptoms related to HYPO, whereas Huber et al. (16) found that the hypothyroid symptom score they used gave results well within the normal range throughout the 9-year follow-up period.

The considerable overlap in traditional hypothyroid symptoms between hypothyroid patients and euthyroid controls also reported by Canaris et al. (54) makes hypothyroid symptom scores quite unreliable as indicator of change in thyroid function in patients with SCH. Monitoring of patients with $\mathrm{SCH}$ should primarily be based on thyroid function testing, keeping in mind that TSH is a less sensitive marker of HYPO in elderly compared to younger patients (55-57).

\section{Influence of $T_{4}$ estimation method and control interval on diagnostic outcome of SCH}

An estimate of $\mathrm{T}_{4}$ within or below the reference range is the biochemical difference between SCH and HYPO. We studied the effect of using different $\mathrm{T}_{4}$ estimates on the probability of diagnosing HYPO in SCH patients by using three different estimates of $\mathrm{T}_{4}: \mathrm{fT}_{4}$ by automated analogue-based method, total $\mathrm{T}_{4}$ and the total $\mathrm{T}_{4} / \mathrm{TBG}$ ( $\mathrm{T}_{4}$ binding globulin) ratio (58). In the calculations, the patients were investigated in a theoretical setting with visits every third month, and it was assumed that treatment would commence when thyroid function tests corresponded to HYPO and further control would cease if thyroid function tests were normal. The diagnostic outcome of monitoring SCH for 1 year was significantly different for the three $\mathrm{T}_{4}$ estimates as shown in Fig. 2 . 


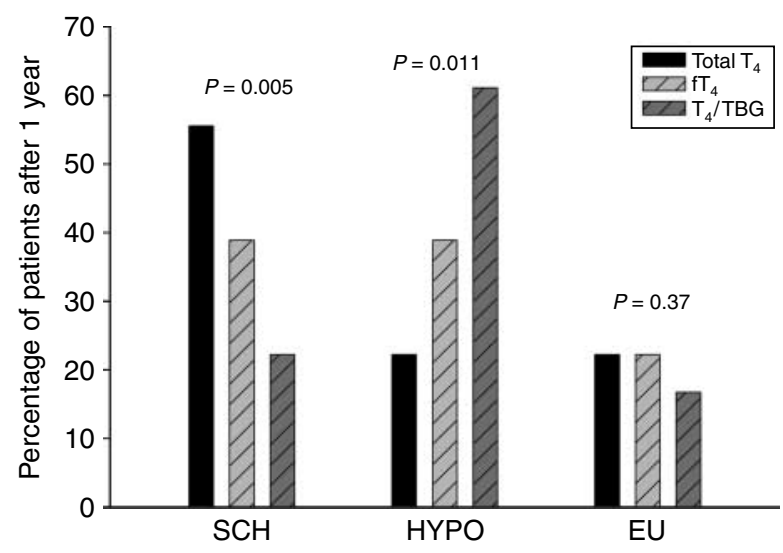

Figure 2 The effect of using different serum $\mathrm{T}_{4}$ estimation methods on the percentage of patients diagnosed to have either hypothyroidism (HYPO), subclinical hypothyroidsm $(\mathrm{SCH})$ or normal thyroid function (EU) after 1 year of observation in patients initially diagnosed with $\mathrm{SCH}(n=18)$. It was assumed that the patients were tested every third month for a year or until the development of HYPO or EU. HYPO was diagnosed when serum TSH was above $4.2 \mathrm{mU} / \mathrm{l}$ and the $\mathrm{T}_{4}$ estimate below normal, $\mathrm{SCH}$ was $\mathrm{TSH}$ above $4.2 \mathrm{mU} / \mathrm{l}$ and a normal $\mathrm{T}_{4}$ estimate, and $\mathrm{EU}$ was TSH between 0.3 and $4.2 \mathrm{mU} / \mathrm{l}$ and a normal $\mathrm{T}_{4}$ estimate. The $\mathrm{T}_{4}$ reference ranges were $60-140 \mathrm{nmol} / \mathrm{l}$ for total $\mathrm{T}_{4}$ (black bars), $12-22 \mathrm{pmol} / \mathrm{l}$ for free $\mathrm{T}_{4}$ (light grey bars) and $3.7-7.3 \mathrm{nmol} / \mathrm{mg}$ for the $\mathrm{T}_{4} / \mathrm{TBG}$ ratio (dark grey bars). The $P$ values for the differences were calculated using Cochrans $Q$ test. See Ref. (58) for further details.

A 75\% higher probability of diagnosing HYPO was found when using the $\mathrm{fT}_{4}$ assay compared to the total $\mathrm{T}_{4}$ assay.

Even though $\mathrm{T}_{4}$ is normal in $\mathrm{SCH}$, it is often low in the reference interval. As discussed above, both TSH and $\mathrm{T}_{4}$ display considerable biological intra-individual variation also in patients with $\mathrm{SCH}$. Thus, there is a certain probability of both TSH and $\mathrm{T}_{4}$ being either normal or abnormal during certain time intervals. With repeated testing of biochemical thyroid function, a change in diagnosis due to variation is likely, and it may be speculated that a higher frequency of testing will increase the likelihood of diagnosing either normalisation of thyroid function or deterioration with development of HYPO.

Indeed, when investigating the effect of using different intervals between control visits, the probability of diagnosing HYPO in SCH patients was found to increase significantly with increasing number of controls per year (58). The risk of diagnosing HYPO increased $45 \%$ with quarterly and 58\% with monthly controls, compared to yearly controls. Additionally, the precise level of the lower $\mathrm{fT}_{4}$ reference limit influenced the probability of diagnosing HYPO considerably (58).

Some of the differences in the observed probability of developing HYPO or normal thyroid function test between the studies listed in Table 1 are most likely due to differences in subtypes of disease in included patients, different screening procedures prior to inclusion of the patients and differences in age of the included patients. However, differences in interval between the thyroid function tests, $\mathrm{T}_{4}$ estimation method and $\mathrm{T}_{4}$ assay lower reference limit also significantly influence the probability of classifying patients as HYPO rather than SCH.

\section{Recommendations for monitoring in untreated SCH}

This review presents evidence to guide monitoring of $\mathrm{SCH}$, and some recommendations may be deduced as listed in Box 1. These are, however, the authors' interpretation of the available data, and no randomised studies comparing various monitoring programmes have been performed. As indicated (Box 1), a single

\section{Box 1 Recommendations for monitoring untreated SCH}

- Measurement of serum TSH and $\mathrm{T}_{4}$ is a cornerstone in monitoring $\mathrm{SCH}$, but additional evaluation of symptoms and signs of hypothyroidism should be performed.

- A validated assay with an appropriately established assay-specific reference interval should be used for $T_{4}$. Change in $\mathrm{T}_{4}$ estimation method during the monitoring should be avoided.

- Initial diagnosis of SCH should be confirmed by the measurement of TSH, $\mathrm{T}_{4}$ and TPO-Ab after 8-12 weeks.

- If normal: no further evaluation is needed.

- If $\mathrm{SCH}$ is persistent:

i) Thyroid function should be evaluated every 6 months the first 2 years.

ii) Thyroid function should be evaluated every year after 2 years.

iii) Patients without symptoms, TPO-Ab or goitre can stop control after 3 years.

iv) After 3 years thyroid function should be evaluated if the patient gets pregnant, develop hypothyroid symptoms or concomitantly with general health evaluations.

- A decrease in thyroid function is suggested when:

TSH rises more than $40 \%$.

$\mathrm{T}_{4}$ decreases by more than $15 \%$. 
TSH above the reference range, but below $10 \mathrm{mU} / \mathrm{l}$, should be followed by a confirmatory measurement of serum TSH, an estimate of $\mathrm{T}_{4}$ and a TPO-Ab measurement after 8-12 weeks. The majority of patients will most likely have a normal TSH on repeated testing, and further testing will be of little value (59). Serial TPO-Ab measurement in antibody-positive individuals is not recommended.

If TSH remains above the upper limit of the reference interval, yearly testing complies with a conversion rate for the development of HYPO in SCH patients in the order of $5 \%$ (Table 1). In the individual patient, the rate of progression of thyroid failure is usually slow, and once or twice yearly, biochemical evaluation of thyroid function is sufficient. We suggest evaluation of thyroid function every 6 months the first 2 years and after 2 years, once yearly evaluations. SCH patients without symptoms, goitre or TPO-Ab have particularly low risk of developing HYPO (17), and in such patients, control can be stopped after 3 years.

Whether to commence $\mathrm{L}_{-} \mathrm{T}_{4}$ treatment or not is an issue between the patient and the physician. They should keep in mind that the difference between two tests should exceed $40 \%$ in serum TSH and $15 \%$ in $\mathrm{T}_{4}$ to suggest a true change in thyroid function.

\section{Conclusion}

$\mathrm{SCH}$ is a condition that can progress to HYPO or regress to normal thyroid function, but often it remains relatively stable for long periods. In the many patients where $\mathrm{L}_{-} \mathrm{T}_{4}$ replacement therapy is not commenced, regular monitoring of the patients is recommended, and criteria for when to start therapy and when to repeat thyroid tests are necessary. No evidence-based recommendations exist on how monitoring should be performed.

When monitoring it should be taken into account that the intra-individual variation in serum TSH resembles that of euthyroid individuals and that the variation in $\mathrm{fT}_{4}$ and $\mathrm{fT}_{3}$ is approximately half that of euthyroid individuals. Changes in TPO-Ab parallel changes in TSH, and consequently, serial measurements of TPO-Ab add little valuable information. Serial evaluation of symptoms and signs related to HYPO is customary when controlling the patients, but they are quite unreliable for evaluation of thyroid function as they associate neither to serum TSH nor to biochemical diagnoses.

Differences in the monitoring procedure may have considerable impact on the diagnostic outcome when monitoring patients with SCH. Specifically, the interval between visits, the type of $\mathrm{T}_{4}$ estimate used and the lower $\mathrm{T}_{4}$ reference limit influence the outcome when untreated $\mathrm{SCH}$ patients are followed.

We suggest that patients with confirmed SCH and who are not treated with $\mathrm{L}_{-} \mathrm{T}_{4}$ should have serum TSH and $\mathrm{T}_{4}$ measurements and symptoms and signs evaluated every 6 months and after 2 years with stable values, the interval between monitoring can be extended. However, randomised studies on how to monitor untreated SCH patients are needed.

\section{Declaration of interest}

The authors declare that there is no conflict of interest that could be perceived as prejudicing the impartiality of the review reported.

\section{Funding}

Nordjyske Lægekredsforenings Forskningsfond and Speciallæge Heinrich Kopps legat granted important economic support, and Roche and BRAHMS provided the reagents for the thyroid function tests and the thyroid auto-antibodies.

\section{Acknowledgements}

The laboratory technicians Ingelise Leegaard, Anne-Mette Christensen and Anette Godsk skilfully carried out the biochemical analyses.

\section{References}

1 Hoogendoorn EH, Hermus AR, de Vegt F, Ross HA, Verbeek AL, Kiemeney LA, Swinkels DW, Sweep FC \& den Heijer M. Thyroid function and prevalence of anti-thyroperoxidase antibodies in a population with borderline sufficient iodine intake: influences of age and sex. Clinical Chemistry 200652 104-111. (doi:10.1373/ clinchem.2005.055194)

2 Knudsen N, Bulow I, Jorgensen T, Laurberg P, Ovesen L \& Perrild H. Comparative study of thyroid function and types of thyroid dysfunction in two areas in Denmark with slightly different iodine status. European Journal of Endocrinology $2000 \mathbf{1 4 3}$ 485-491. (doi:10.1530/eje.0.1430485)

3 Lindeman RD, Schade DS, LaRue A, Romero LJ, Liang HC, Baumgartner RN, Koehler KM \& Garry PJ. Subclinical hypothyroidism in a biethnic, urban community. Journal of the American Geriatrics Society 199947 703-709.

4 Laurberg P, Pedersen KM, Hreidarsson A, Sigfusson N, Iversen E \& Knudsen PR. Iodine intake and the pattern of thyroid disorders: a comparative epidemiological study of thyroid abnormalities in the elderly in Iceland and in Jutland, Denmark. Journal of Clinical Endocrinology and Metabolism 1998 83 765-769. (doi:10.1210/jc. 83.3.765)

5 Teng W, Shan Z, Teng X, Guan H, Li Y, Teng D, Jin Y, Yu X, Fan C, Chong W, Yang F, Dai H, Yu Y, Li J, Chen Y, Zhao D, Shi X, Hu F, Mao J, Gu X, Yang R, Tong Y, Wang W, Gao T \& Li C. Effect of iodine intake on thyroid diseases in China. New England Journal of Medicine 2006354 2783-2793. (doi:10.1056/NEJMoa054022)

6 Tunbridge WM, Evered DC, Hall R, Appleton D, Brewis M, Clark F, Evans JG, Young E, Bird T \& Smith PA. The spectrum of thyroid disease in a community: the Whickham Survey. Clinical Endocrinology $1977 \quad 7$ 481-493. (doi:10.1111/j.1365-2265. 1977.tb01340.x)

7 Walsh JP, Bremner AP, Feddema P, Leedman PJ, Brown SJ \& O'Leary P. Thyrotropin and thyroid antibodies as predictors of hypothyroidism: a 13-year, longitudinal study of a communitybased cohort using current immunoassay techniques. Journal of Clinical Endocrinology and Metabolism $2010 \quad 95$ 1095-1104. (doi:10.1210/jc.2009-1977)

8 Hollowell JG, Staehling NW, Flanders WD, Hannon WH, Gunter EW, Spencer CA \& Braverman LE. Serum TSH, T(4), and thyroid antibodies in the United States population (1988 to 1994): 
National Health and Nutrition Examination Survey (NHANES III). Journal of Clinical Endocrinology and Metabolism 2002 87 489-499. (doi:10.1210/jc.87.2.489)

9 Carle A, Laurberg P, Pedersen IB, Knudsen N, Perrild H, Ovesen L, Rasmussen LB \& Jorgensen T. Epidemiology of subtypes of hypothyroidism in Denmark. European Journal of Endocrinology 2006154 21-28. (doi:10.1530/eje.1.02068)

10 Nystrom E, Bengtsson C, Lindquist O, Noppa H, Lindstedt G \& Lundberg PA. Thyroid disease and high concentration of serum thyrotrophin in a population sample of women. A 4-year followup. Acta Medica Scandinavica 1981210 39-46. (doi:10.1111/ j.0954-6820.1981.tb09773.x)

11 Tunbridge WM, Brewis M, French JM, Appleton D, Bird T, Clark F, Evered DC, Evans JG, Hall R, Smith P, Stephenson J \& Young E. Natural history of autoimmune thyroiditis. BMJ $1981 \mathbf{2 8 2}$ 258-262. (doi:10.1136/bmj.282.6260.258)

12 Gray RS, Borsey DQ, Irvine WJ, Seth J \& Clarke BF. Natural history of thyroid function in diabetics with impaired thyroid reserve: a four year controlled study. Clinical Endocrinology 198319 445-451. (doi:10.1111/j.1365-2265.1983.tb00018.x)

13 Rosenthal MJ, Hunt WC, Garry PJ \& Goodwin JS. Thyroid failure in the elderly. Microsomal antibodies as discriminant for therapy. Journal of the American Medical Association 1987258 209-213. (doi:10.1001/jama.258.2.209)

14 Parle JV, Franklyn JA, Cross KW, Jones SC \& Sheppard MC. Prevalence and follow-up of abnormal thyrotrophin (TSH) concentrations in the elderly in the United Kingdom. Clinical Endocrinology 199134 77-83. (doi:10.1111/j.1365-2265.1991. tb01739.x)

15 Kabadi UM. 'Subclinical hypothyroidism'. Natural course of the syndrome during a prolonged follow-up study. Archives of Internal Medicine 1993153 957-961. (doi:10.1001/archinte.153.8.957)

16 Huber G, Staub JJ, Meier C, Mitrache C, Guglielmetti M, Huber P \& Braverman LE. Prospective study of the spontaneous course of subclinical hypothyroidism: prognostic value of thyrotropin, thyroid reserve, and thyroid antibodies. Journal of Clinical Endocrinology and Metabolism 200287 3221-3226. (doi:10. $1210 /$ jc.87.7.3221)

17 Diez JJ \& Iglesias P. Spontaneous subclinical hypothyroidism in patients older than 55 years: an analysis of natural course and risk factors for the development of overt thyroid failure. Journal of Clinical Endocrinology and Metabolism $2004 \quad 89$ 4890-4897. (doi:10.1210/jc.2003-032061)

18 Rosario PW, Bessa B, Valadao MM \& Purisch S. Natural history of mild subclinical hypothyroidism: prognostic value of ultrasound. Thyroid 200919 9-12. (doi:10.1089/thy.2008.0221)

19 Chu JW \& Crapo LM. The treatment of subclinical hypothyroidism is seldom necessary. Journal of Clinical Endocrinology and Metabolism 200186 4591-4599. (doi:10.1210/jc.86.10.4591)

20 McDermott MT \& Ridgway EC. Subclinical hypothyroidism is mild thyroid failure and should be treated. Journal of Clinical Endocrinology and Metabolism 200186 4585-4590. (doi:10. $1210 /$ jc.86.10.4585)

21 Vanderpump M. Subclinical hypothyroidism: the case against treatment. Trends in Endocrinology and Metabolism $2003 \mathbf{1 4}$ 262-266. (doi:10.1016/S1043-2760(03)00103-6)

22 Owen PJ \& Lazarus JH. Subclinical hypothyroidism: the case for treatment. Trends in Endocrinology and Metabolism $2003 \mathbf{1 4}$ 257-261. (doi:10.1016/S1043-2760(03)00108-5)

23 Surks MI, Ortiz E, Daniels GH, Sawin CT, Col NF, Cobin RH, Franklyn JA, Hershman JM, Burman KD, Denke MA, Gorman C, Cooper RS \& Weissman NJ. Subclinical thyroid disease: scientific review and guidelines for diagnosis and management. Journal of the American Medical Association 2004291 228-238. (doi:10. 1001/jama.291.2.228)

24 Gharib H, Tuttle RM, Baskin HJ, Fish LH, Singer PA \& McDermott MT. Subclinical thyroid dysfunction: a joint statement on management from the American Association of Clinical Endocrinologists, the American Thyroid Association, and the Endocrine Society. Journal of Clinical Endocrinology and Metabolism 200590 581-585. (doi:10.1210/jc.2004-1231)
25 Biondi B \& Cooper DS. The clinical significance of subclinical thyroid dysfunction. Endocrine Reviews 200829 76-131. (doi:10. 1210/er.2006-0043)

26 Rodondi N, den Elzen WP, Bauer DC, Cappola AR, Razvi S, Walsh JP, Asvold BO, Iervasi G, Imaizumi M, Collet TH, Bremner A, Maisonneuve P, Sgarbi JA, Khaw KT, Vanderpump MP, Newman AB, Cornuz J, Franklyn JA, Westendorp RG, Vittinghoff E \& Gussekloo J. Subclinical hypothyroidism and the risk of coronary heart disease and mortality. Journal of the American Medical Association 2010304 1365-1374. (doi:10.1001/jama. 2010.1361)

27 Villar HC, Saconato H, Valente O \& Atallah AN. Thyroid hormone replacement for subclinical hypothyroidism. Cochrane Database of Systematic Reviews, 2007 CD003419. (doi:10.1002/14651858)

28 Panicker V, Wilson SG, Spector TD, Brown SJ, Falchi M, Richards JB, Surdulescu GL, Lim EM, Fletcher SJ \& Walsh JP. Heritability of serum TSH, free $\mathrm{T}_{4}$ and free $\mathrm{T}_{3}$ concentrations: a study of a large UK twin cohort. Clinical Endocrinology 200868 652-659. (doi:10.1111/j.1365-2265.2007.03079.x)

29 Hansen PS, Brix TH, Sorensen TI, Kyvik KO \& Hegedus L. Major genetic influence on the regulation of the pituitary-thyroid axis: a study of healthy danish twins. Journal of Clinical Endocrinology and Metabolism 2004 89 1181-1187. (doi:10.1210/jc.2003-031641)

30 Andersen S, Pedersen KM, Bruun NH \& Laurberg P. Narrow individual variations in serum $\mathrm{T}(4)$ and $\mathrm{T}(3)$ in normal subjects: a clue to the understanding of subclinical thyroid disease. Journal of Clinical Endocrinology and Metabolism 200287 1068-1072. (doi:10.1210/jc.87.3.1068)

31 Maes M, Mommen K, Hendrickx D, Peeters D, D’Hondt P, Ranjan R, De Meyer F \& Scharpe S. Components of biological variation, including seasonality, in blood concentrations of TSH, $\mathrm{TT}_{3}, \mathrm{FT}_{4}$, PRL, cortisol and testosterone in healthy volunteers. Clinical Endocrinology 199746 587-598. (doi:10.1046/j.13652265.1997.1881002.x)

32 Nagayama I, Yamamoto K, Saito K, Kuzuya T \& Saito T. Subjectbased reference values in thyroid function tests. Endocrine Journal 199340 557-562. (doi:10.1507/endocrj.40.557)

33 Meier CA, Maisey MN, Lowry A, Muller J \& Smith MA. Interindividual differences in the pituitary-thyroid axis influence the interpretation of thyroid function tests. Clinical Endocrinology 199339 101-107. (doi:10.1111/j.1365-2265.1993.tb01758.x)

34 Brabant G, Prank K, Ranft U, Schuermeyer T, Wagner TO, Hauser H, Kummer B, Feistner H, Hesch RD \& von zur MA. Physiological regulation of circadian and pulsatile thyrotropin secretion in normal man and woman. Journal of Clinical Endocrinology and Metabolism 199070 403-409. (doi:10.1210/jcem-70-2-403)

35 Browning MC, Ford RP, Callaghan SJ \& Fraser CG. Intra- and interindividual biological variation of five analytes used in assessing thyroid function: implications for necessary standards of performance and the interpretation of results. Clinical Chemistry 198632 962-966.

36 Harrop JS, Ashwell K \& Hopton MR. Circannual and withinindividual variation of thyroid function tests in normal subjects. Annals of Clinical Biochemistry 198522 371-375.

37 Feldt-Rasmussen U, Hyltoft PP, Blaabjerg O \& Horder M. Long-term variability in serum thyroglobulin and thyroid related hormones in healthy subjects. Acta Endocrinologica 198095 328-334. (doi:10.1530/acta.0.0950328)

38 Andersen S, Bruun NH, Pedersen KM \& Laurberg P. Biologic variation is important for interpretation of thyroid function tests. Thyroid 200313 1069-1078. (doi:10.1089/105072503770 867237)

39 Karmisholt J, Andersen S \& Laurberg P. Analytical goals for thyroid function tests when monitoring patients with untreated subclinical hypothyroidism. Scandinavian Journal of Clinical and

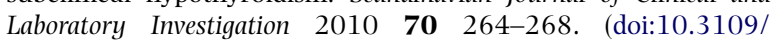
00365511003782778 )

40 Fraser CG. Changes in serial results. In Biological Variation: From Principles to Practice, ch 3, pp 67-90. Ed C-G Fraser. Washington, DC: AACC Press, 2001. 
41 Petersen PH, Sandberg S, Fraser CG \& Goldschmidt H. Influence of index of individuality on false positives in repeated sampling from healthy individuals. Clinical Chemistry and Laboratory Medicine 200139 160-165. (doi:10.1515/CCLM.2001.027)

42 Karmisholt J, Andersen S \& Laurberg P. Variation in thyroid function tests in patients with stable untreated subclinical hypothyroidism. Thyroid 200818 303-308. (doi:10.1089/thy.2007.0241)

43 Karmisholt J \& Laurberg P. Serum TSH and serum thyroid peroxidase antibody fluctuate in parallel and high urinary iodine excretion predicts subsequent thyroid failure in a 1-year study of patients with untreated subclinical hypothyroidism. European Journal of Endocrinology 2008158 209-215. (doi:10.1530/EJE07-0407)

44 Reinhardt W, Luster M, Rudorff KH, Heckmann C, Petrasch S, Lederbogen S, Haase R, Saller B, Reiners C, Reinwein D \& Mann K. Effect of small doses of iodine on thyroid function in patients with Hashimoto's thyroiditis residing in an area of mild iodine deficiency. European Journal of Endocrinology 1998139 23-28. (doi:10.1530/eje.0.1390023)

45 Kahaly GJ, Dienes HP, Beyer J \& Hommel G. Iodide induces thyroid autoimmunity in patients with endemic goitre: a randomised, double-blind, placebo-controlled trial. European Journal of Endocrinology 1998139 290-297. (doi:10.1530/eje.0.1390290)

46 Vanderpump MP, Tunbridge WM, French JM, Appleton D, Bates D, Clark F, Grimley EJ, Hasan DM, Rodgers H, Tunbridge F \& Young ET. The incidence of thyroid disorders in the community: a twenty-year follow-up of the Whickham Survey. Clinical Endocrinology $1995 \mathbf{4 3}$ 55-68. (doi:10.1111/j.1365-2265.1995.tb01894.x)

47 Kong WM, Sheikh MH, Lumb PJ, Naoumova RP, Freedman DB, Crook M, Dore CJ, Finer N \& Naoumova P. A 6-month randomized trial of thyroxine treatment in women with mild subclinical hypothyroidism. American Journal of Medicine 2002112 348-354. (doi:10.1016/SO002-9343(02)01022-7)

48 Meier C, Staub JJ, Roth CB, Guglielmetti M, Kunz M, Miserez AR, Drewe J, Huber P, Herzog R \& Muller B. TSH-controlled L-thyroxine therapy reduces cholesterol levels and clinical symptoms in subclinical hypothyroidism: a double blind, placebo-controlled trial (Basel Thyroid Study). Journal of Clinical Endocrinology and Metabolism 200186 4860-4866. (doi:10.1210/jc.86.10.4860)

49 Cooper DS, Halpern R, Wood LC, Levin AA \& Ridgway EC. L-thyroxine therapy in subclinical hypothyroidism. A doubleblind, placebo-controlled trial. Annals of Internal Medicine 1984 $10118-24$.

50 Nystrom E, Caidahl K, Fager G, Wikkelso C, Lundberg PA \& Lindstedt G. A double-blind cross-over 12-month study of L-thyroxine treatment of women with 'subclinical' hypothyroidism. Clinical Endocrinology 198829 63-75. (doi:10.1111/j.13652265.1988.tb00250.x)
51 Jaeschke R, Guyatt G, Gerstein H, Patterson C, Molloy W, Cook D, Harper S, Griffith L \& Carbotte R. Does treatment with L-thyroxine influence health status in middle-aged and older adults with subclinical hypothyroidism? Journal of General Internal Medicine 199611 744-749. (doi:10.1007/BF02598988)

52 Jorde R, Waterloo K, Storhaug H, Nyrnes A, Sundsfjord J \& Jenssen TG. Neuropsychological function and symptoms in subjects with subclinical hypothyroidism and the effect of thyroxine treatment. Journal of Clinical Endocrinology and Metabolism 2006 91 145-153. (doi:10.1210/jc.2005-1775)

53 Razvi S, Ingoe L, Keeka G, Oates C, McMillan C \& Weaver JU. The beneficial effect of L-thyroxine on cardiovascular risk factors, endothelial function, and quality of life in subclinical hypothyroidism: randomized, crossover trial. Journal of Clinical Endocrinology and Metabolism 200792 1715-1723. (doi:10. 1210/jc.2006-1869)

54 Canaris GJ, Steiner JF \& Ridgway EC. Do traditional symptoms of hypothyroidism correlate with biochemical disease? Journal of General Internal Medicine 199712 544-550. (doi:10.1046/j. 1525-1497.1997.07109.x)

55 Wiener R, Utiger RD, Lew R \& Emerson CH. Age, sex, and serum thyrotropin concentrations in primary hypothyroidism. Acta Endocrinologica $1991 \quad \mathbf{1 2 4} \quad 364-369 . \quad$ (doi:10.1530/acta.0. 1240364)

56 Carle A, Laurberg P, Pedersen IB, Perrild H, Ovesen L, Rasmussen LB, Jorgensen T \& Knudsen N. Age modifies the pituitary TSH response to thyroid failure. Thyroid $2007 \mathbf{1 7}$ 139-144. (doi:10.1089/thy.2006.0191)

57 Over R, Mannan S, Nsouli-Maktabi H, Burman KD \& Jonklaas J. Age and the thyrotropin response to hypothyroxinemia. Journal of Clinical Endocrinology and Metabolism $2010 \quad 95$ 3675-3683. (doi:10.1210/jc.2010-0281)

58 Karmisholt J, Andersen S \& Laurberg P. Interval between tests and $\mathrm{T}_{4}$ estimation method influence outcome of monitoring of subclinical hypothyroidism. Journal of Clinical Endocrinology and Metabolism 200893 1634-1640. (doi:10.1210/jc. 2008-0101)

59 Meyerovitch J, Rotman-Pikielny P, Sherf M, Battat E, Levy Y \& Surks MI. Serum thyrotropin measurements in the community: five-year follow-up in a large network of primary care physicians. Archives of Internal Medicine 2007 167 1533-1538. (doi:10. 1001/archinte.167.14.1533)

Received 22 December 2010

Accepted 5 January 2011 